\title{
OPERASI APIK UNTUK GUNUNG CIKURAY BERSIH, SEHAT, DAN LESTARI
}

\author{
Nurfadhilah $^{1}$, lis komalasari ${ }^{2}$, Agung prabawa ${ }^{2}$ \\ ${ }^{1}$ Program Studi Kesehatan Masyarakat, FKM Universitas Muhammadiyah Jakarta, \\ Jalan KH Ahmad Dahlan, Cireundeu, Tangerang Selatan, 16519 \\ ${ }^{2}$ Relawan Porter Indonesia, Jln.kopo Gg parasdi no.22 \\ email: nurfadhilah.nf@umj.ac.id
}

\begin{abstract}
ABSTRAK
Mendaki gunung merupakan kegiatan olahraga sekaligus rekreasi yang dalam situasi tertentu mengakibatkan tumpukan sampah tertinggal di berbagai lokasi (puncak, sekitar kemah, dan sepanjang lintasan). Kegiatan bernama Operasi Bersih Sampah Gunung Cikuray bertujuan membersihkan lokasi terjangkau dari sampah, khususnya yang berbahan plastik. Kegiatan dilaksanakan pada Sabtu-Ahad, 29-30 Agustus 2020 melalui Kiara Janggot, Kota Garut, Jawa Barat. Kegiatan diikuti 52 orang dengan peserta termuda berusia 9 tahun dan tertua 45 tahun, 38 lelaki dan 14 perempuan. Sampah yang berhasil dikumpulkan dan dibawa ke kaki gunung berjumlah sekitar 60 kantong ukuran $3 \mathrm{~kg}$ dan $15 \mathrm{karung}$ ukuran $20 \mathrm{~kg}$, total sekitar $400 \mathrm{~kg}$. Jenis sampah umumnya botol (botol plastik berisi urin, botol AMDK, botol minuman keras, tutup botol), pembalut, tisu, bungkus permen, bungkus mi instan, dan puntung rokok. Kegiatan ini sangat bermanfaat, selain bagi kebersihan, kesehatan, dan kelestarian lingkungan, juga bagi individu yang mengikuti kegiatan, baik secara fisik maupun mental.
\end{abstract}

Kata Kunci: operasi, bersih, gunung, Cikuray.

\begin{abstract}
Mountain climbing is a sport as well as recreational activity which in certain situations results in piles of garbage left in various locations (at the top, around the camp, and along the trails). The activity called Operation Mount Cikuray Garbage Cleanup aims to clean up affordable locations from rubbish, especially those made of plastic. The activity was carried out on Saturday-Sunday, 29-30 August 2020 through Kiara Janggot, Garut City, West Java. The activity was attended by 52 people with the youngest participants aged 9 years and the oldest 45 years, 38 men and 14 women. The garbage collected and brought to the foot of the mountain is around 60 and 1520 $\mathrm{kg}$ sacks, a total of about $400 \mathrm{~kg}$. Types of waste are generally bottles (plastic bottles containing urine, bottled drinking water bottles, liquor bottles, bottle caps), sanitary napkins, tissue wrappers, instant noodle wrappers, and cigarette butts. This activity is very beneficial, in addition to cleanliness, health and environmental sustainability, as well as for individuals who participate in the activity, both physically and mentally.
\end{abstract}

Keywords: operation, clean, mount, Cikuray. 
Volume. 1 No. 2 tahun 2020

Mei 2020 - November 2020
ISSN (online): 2722-2055 https://jurnal.umj.ac.id/
AS-SYIFA: Jurnal Pengabdian dan Pemberdayaan Kesehatan Masyarakat

\section{PENDAHULUAN}

Masalah yang selalu dihadapi kawasan wisata yaitu sampah, tidak terkecuali kawasan gunung. Timbunan sampah terus meninggi seiring bertambahnya jumlah pendaki (1). Situasi Pandemi sangat membatasi mobilitas penduduk dan meningkatkan tekanan psikologis. Beberapa gunung juga dalam kondisi aktif sehingga tidak memungkinkan untuk didaki. Gunung cikuray memiliki 7 jalur alternatif pendakian, salah satunya melalui Kiara Janggot (2).

Tujuan pengabdian masyarakat yaitu membersihkan lokasi yang dapat dijangkau dari tumpukan sampah. Kegiatan ini diharapkan bermanfaat bagi kesatuan dan jalinan silaturrahim peserta sekaligus kebersihan, keindahan, dan kelestarian Gunung Cikuray.

\section{METODE}

Kegiatan dilaksanakan di Gunung Cikuray melalui jalur Kiara Janggot pada 29-30 Agustus 2020. Seluruh peserta sudah hadir di basecamp Kiara Janggot pada Sabtu 29 Agustus dan berangkat pada pukul 08.15.

Peserta dijadwalkan tiba di pos 8 pukul 18.00. Panitia membagikan trash bag dan karung di pos 8 dan puncak. Kegiatan operasi bersih dilaksanakan pada Ahad, 30 Agustus pukul 08-09 untuk selanjutnya sampah akan dibawa ke basecamp.

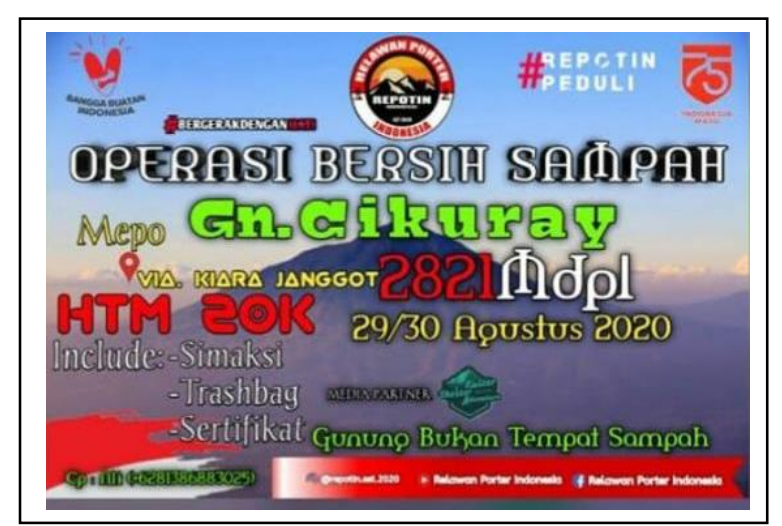

Gambar 1. Broadcast kegiatan

Kegiatan diinisiasi oleh Relawan Porter Indonesia (REPOTIN) dan bermitra dengan Relawan Pramuka Kwarcab Kota Bekasi dan Shelter Kalcer Adv. Beberapa peserta mendaftarkan diri secara mandiri setelah mendapat informasi dari media sosial FaceBook dan WhatsApp.

\section{HASIL DAN PEMBAHASAN}

Setelah beberapa pekan persiapan dan registrasi, dilaksanakanlah Operasi Bersih Gunung Ciparay. Kegiatan diikuti 52 orang dengan peserta termuda berusia 9 tahun dan tertua 45 tahun, 38 lelaki dan 14 perempuan.

\section{a. Pendaki pemula}

SALAH satu pendaki pemula yang juga merupakan peserta termuda masih duduk di Kelas IV SD dan pada saat kegiatan berlangsung masih melaksanakan pembelajaran sehingga buku pelajaran dibawa serta. Sebelum mulai mendaki, tugas sekolahnya diselesaikan. 
Volume. 1 No. 2 tahun 2020 Mei 2020 - November 2020 https://jurnal.umj.ac.id/
AS-SYIFA: Jurnal Pengabdian dan Pemberdayaan Kesehatan Masyarakat

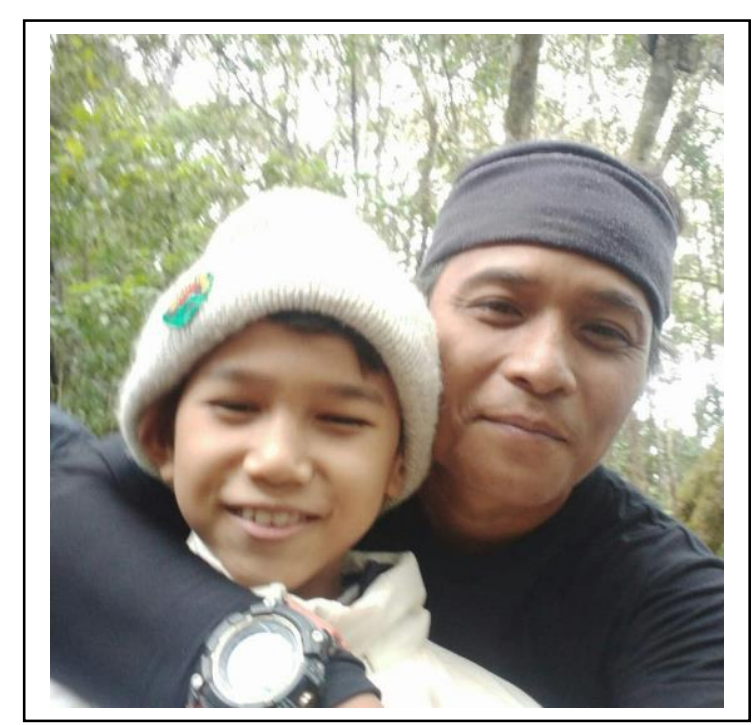

Gambar 2. Peserta termuda dan tertua

Bagi peserta termuda ini merupakan pengalaman pendakian pertama, dan ia menantikan dengan penuh semangat. Sejak awal ia terlihat tidak sabar ingin segera mulai mendaki. Ia berada di barisan terdepan dengan membawa sendiri tas punggungnya dan bertahan di barisan terdepan hingga pos 8. Demikian juga ketika kembali/menuruni gunung. Hal ini membuktikan bahwa keikutsertaan anak dan remaja cukup menambah semangat peserta lain dan relatif tidak membebani panitia. Memang setelah mencapai jarak tertentu ia membutuhkan bantuan untuk membawa barangnya, namun ia terlihat memiliki perasaan positif (3) dan basecamp. mempertahankannya hingga kembali ke

Pendaki pemula melakukan beberapa persiapn sebelum mendaki. Konsumsi barang berupa peralatan pendakian bisa didapat dengan meminjam atau membeli. Mereka juga melakukan persiapan fisik dan olah raga. Sebagian pendaki pemula memiliki optimisme, namun sebagian lain relatif pesimis (4).

\section{b. Volume dan jenis sampah}

Sampah yang berhasil dikumpulkan dan dibawa ke kaki gunung berjumlah sekitar 60 dan 15 karung ukuran $20 \mathrm{~kg}$, total sekitar 400 $\mathrm{kg}$. Jenis sampah umumnya botol (botol plastik berisi urin, botol air minum dalam kemasan (AMDK), botol minuman keras, tutup botol), pembalut, tisu, bungkus permen, bungkus mi instan, dan puntung rokok.

Sebagai pembanding, timbulan sampah yang dihasilkan oleh para pendaki di Gunung Andong Via Jalur Pendakian Dusun Sawit yaitu $0,108-0,154 \mathrm{~kg} /$ orang/hari dengan komposisi sampah (\% berat) yang terbanyak adalah plastik $(33,7 \%)$ terdiri dari botol plastik (13\%), bungkus makanan $(9,2 \%)$, kantong kresek $(6,4 \%)$, gelas plastik $(5,1 \%)$, sisa makanan $(25,1 \%)$, tisu $(8,7 \%)$, karton $(4,6 \%)$,

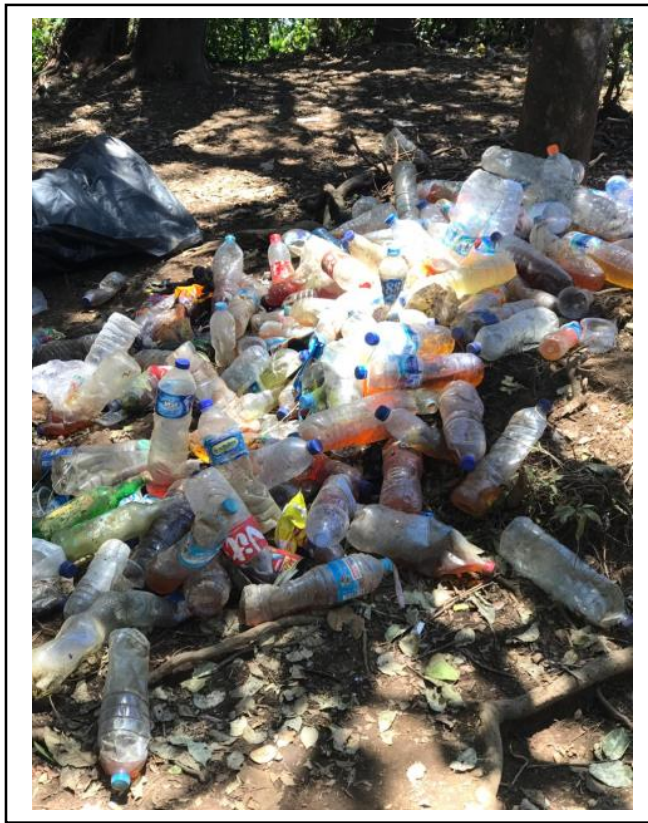

Gambar 3. Sampah botol plastik kaca $(3,4 \%)$, kertas $(2,8 \%)$, logam $(1,8 \%)$, B3 (1,5\%), styrofoam $(1,4 \%)$, dan tekstil $(1,1 \%)$. Sekitar 25,1\% sampah di Gunung Andong berpotensi untuk pengomposan dan $56,4 \%$ dari total sampah tersebut berpotensi untuk didaur ulang dan layak jual kembali (5). 
Keberadaan jenis sampah tertentu juga berhubungan dengan fasilitas yang tersedia di lokasi (6). Sebagai contoh, di Gunung Cikuray, fasilitas untuk buang air kecil maupun besar hanya terdapat di Pos 8 dengan kondisi sangat darurat. Akibatnya, banyak botol berisi urin dan tisu bekas usapan/istinja dibuang sembarangan, tentu mengakibatkan aroma tidak sedap pada beberapa titik.

\section{c. Perilaku merokok dan puntung rokok}

Merokok berkaitan dengan upaya menghangatkan diri saat mendaki gunung yang umumnya bersuhu udara rendah. Pendaki gunung, terutama yang lelaki, umumnya perokok (7); demikian pula situasi para pendaki Gunung Ciparay. Hal ini mengakibatkan keberadaan sampah berupa puntung rokok dapat ditemukan di sepanjang lintasan dan semakin banyak saat mencapai puncak gunung. Bahkan kebakaran pernah terjadi pada 17 Agusutus 2015 yang disinyalir disebabkan puntung rokok dan api unggun yang belum benar-benar padam (5).

Perilaku merokok juga merupakan salah satu yang direkomendasikan untuk dihindari sebagai pencegahan high-altitude illness (HAI) yaitu sekumpulan gejala paru dan otak yang terjadi akibat mendaki ketinggian tertentu (8). Saat pendakian Gunung Ciparay ditemukan beberapa kasus yang disebabkan penurunan suhu tubuh ekstrim (hipotermia), kurang/tidak mencukupi asupan makan/minum, hingga kram pada bagian tubuh tertentu. Antisipasi kasus yang ditemukan dilakukan dengan koordinasi berbagai pihak, yaitu penyelenggara kegiatan, warga setempat, dan relawan serta petugas tiap pos dan basecamp.

Terdapat perbedaan rerata saturasi oksigen yang bermakna antara perokok dataran tinggi dan perokok dataran rendah; perokok dataran tinggi dan bukan perokok dataran rendah; serta perokok dan bukan perokok di dataran tinggi (9). Perilaku merokok sejatinya tidak hanya berbahaya bagi perokok, namun juga lingkungan sekitarnya. Ada fenomena perokok yang membawa botol kaca khusus untuk menampung abu dan puntung rokoknya sendiri agar tidak mencemari lingkungan, namun jumlahnya masih sangat terbatas. Fenomena ini cukup positif bagi mereka yang belum bisa menghentikan perilakunya saat mendaki gunung. Para aktivis mempunyai semboyan yang cukup terkenal "take nothing but picture, leave nothing but footprint, kill nothing but time"(10).

\section{KESIMPULAN DAN SARAN}

Kegiatan ini sangat bermanfaat, selain bagi kebersihan, kesehatan, dan kelestarian lingkungan, juga bagi individu yang mengikuti kegiatan, baik secara fisik maupun mental. Kegiatan perlu dilakukan secara periodik dan melibatkan lebih banyak individu dan komunitas. Berbagai kalangan bisa dilibatkan, bahkan mereka yang masih duduk di jenjang sekolah dasar dan sekolah menengah. Kegiatan ini merupakan alternatif dalam membentuk manusia tangguh yang peduli kepada sesama dan alam sekitar. 
Volume. 1 No. 2 tahun 2020

Mei 2020 - November 2020
ISSN (online): 2722-2055 https://jurnal.umj.ac.id/
AS-SYIFA: Jurnal Pengabdian dan Pemberdayaan Kesehatan Masyarakat

\section{UCAPAN TERIMA KASIH}

Penghargaan dan ucapan terima kasih kami sampaikan kepada Relawan Porter Indonesia (Repotin), Kwarcab Kota Bekasi dan Shelter Kalcer Adv. Secara khusus, ungkapan terima kasih dihaturkan kepada Kang Agung, Teh lis, Kang Asep, dan pihak-pihak lain yang banyak membantu namun namanya belum sempat tercatat dalam laporan ini.

\section{DAFTAR PUSTAKA}

Abdurrahim, M. I., Purnama, H., \& Yuriandala, Y. (2020). Analisis timbulan dan komposisi sampah di gunung andong via jalur pendakian dusun sawit, kabupaten magelang, jawa tengah.

Anuraga, J. L. Y. (2018). Pencinta Alam Sebagai Bentuk Peran Pemuda di Tengah Tantangan Kehidupan Kota. Jurnal Studi Pemuda, 5(2), 447. https://doi.org/10.22146/studipemudaugm.37946

Cikuray, B. (2020). 7 Jalur Pendakian Gunung Cikuray, Garut, Manakah Jalur yang Paling Ideal Untukmu_ - Pendakian Gunung Cikuray (p. 7). https://gunungcikuray.com/2019/07/28/7-jalur-pendakian-gunung-cikuray-garutmanakah-jalur-yang-paling-ideal-untukmu/

Elvira, D. (2015). High-Altirude Illness. Jurnal Kesehatan Andalas, 4(2), 582-589.

Fatwa, U. S. (2017). Tingkat kesadaran para pendaki gunung dalam menjaga lingkungan wisata pendakian gunung ungaran skripsi. Universitas Negeri Semarang.

Fernandez, E., \& Tirtayasa, K. (2017). Gambaran Perubahan pada Pendaki Gunung Batur Mahasiswa Fakultas Kedokteran Universitas Udayana. E-Jurnal Medika, 6(1), 1-5.

Kumalasari, N. L. (2015). Perilaku Penemuan Informasi di Kalangan Pendaki Pemula di Surabaya [Universitas Airlangga]. In Biomass Chem Eng (Vol. 49, Issues 236). http://www.ti.com/lit/ds/symlink/cc2538.html

Nurfadhilah. (2020). Perasaan Positif pada Korban Bencana Alam di Lombok, Sulawesi, dan Banten. As Syifa Jurnal Pengabdian Dan Pemberdayaan Kesehatan Masyarakat, 1(1), 28-36.

Polii, T. R., Rumampuk, J., \& Lintong, F. (2017). Perbandingan Saturasi Oksigen pada Perokok dan Bukan Perokok di Dataran Tinggi Tomohon dan Dataran Rendah Manado. Jurnal E-Biomedik, 5(2). https://doi.org/10.35790/ebm.5.2.2017.18311

Syaputra, M. (2019). Perencanaan pengelolaan sampah di jalur pendakian taman nasional gunung rinjani. Jurnal Belantara, 2(1), 17-23. 
